KREATIF : Jurnal Ilmiah Prodi Manajemen Universitas Pamulang, Volume 8, No. 1, Juni 2020

KREATIF

Jurnal Ilmiah

Prodi Manajemen Universitas Pamulang
ISSN : $2339-0689$, E-ISSN : 2406-8616

J. KREATIF, Vol. 8, No.1, Juni 2020 (Halaman 61-76)

Tersedia Online di: http://openjournal.unpam.ac.id/index.php/kreatif

\title{
PENGARUH RETURN ON ASSETS (ROA) DAN EARNING PER SHARE (EPS) TERHADAP HARGA SAHAM PADA PT. ULTRAJAYA TBK TAHUN 2010 - 2016
}

\author{
Amthy Suraya dan Juni \\ Program Studi Manajemen Fakultas Ekonomi Universitas Pamulang \\ Email: dosen00627@ unpam.ac.id
}

\begin{abstract}
ABSTRAK
Penelitian ini bertujuan untuk menganalisa pengaruh Return On Assets (ROA) dan Earning Per Share (EPS) terhadap Harga Saham perusahaan. Seberapa besar pengaruh dari kedua variabel tersebut untuk mendapatkan keuntungan atas Harga saham.

Metode yang digunakan bersifat deskriptif yang menggunakan data kuantitatif dan data yang diperoleh berasal dari website PT. Ultrajaya Tbk (www.ultrajaya.co.id) dan Bursa Efek Indonesia (www.idx.co.id). Metode yang digunakan dalam penelitian ini adalah analisis linier berganda.

Berdasarkan hasil penelitian regresi linier berganda, didapat persamaan $\mathrm{Y}=1.596,778-134,134 \mathrm{X}_{1}+23.537 \mathrm{X}_{2}+$ e. Dari hasil uji parsial (uji t), maka diperoleh hasil sebagai berikut : ROA tidak berpengaruh signifikan terhadap Harga Saham dengan thitung 0,434 $<2,776$ ttabel dengan taraf signifikansi 0,687 $>0,05$ maka Ho ditolak dan Ha diterima. EPS tidak berpengaruh signifikan terhadap Harga Saham dengan thitung 1,212 < 2,776 dengan taraf signifikansi 0,292 >0,05 maka Ho diterima dan Ha ditolak. Berdasarkan hasil uji signifikansi simultan (uji F) diperoleh hasil fhitung 2,497 < ftabel 6,94 dengan taraf signifikansi 0,198>0,05 maka Ho diterima dan Ha ditolak. Kesimpulan dari perhitungan tersebut adalah Return On Assets dan Earning Per Share secara simultan tidak berpengaruh terhadap Harga Saham.
\end{abstract}

Kata Kunci: Return On Assets; Earning Per Share; Harga Saham.

\section{ABSTRACT}

This study aims to analyze the effect of Return On Assets (ROA) and Earning Per Share (EPS) on the company's stock price. How big is the influence of these two variables to get a return on stock prices.

The method used is descriptive which uses quantitative data and the data obtained comes from the website of PT. Ultrajaya Tbk (www.ultrajaya.co.id) and Indonesia Stock Exchange (www.idx.co.id). The method used in this study is multiple linear analysis.

Based on the results of multiple linear regression studies, the equation $Y=1,596,778-134,134 X 1+23,537 X 2+e$. From the results of the partial test ( $t$ test), the following results are obtained: ROA does not have a significant effect on Stock Prices with tcount $0.434<2.776$ table with a significance level of 0.687> 0.05 so Ho is rejected and Ha is accepted. EPS has no significant effect on Stock Prices with tcount $1.212<2.776$ with a significance level of $0.292>0.05$ so Ho is accepted and $\mathrm{Ha}$ is rejected. Based on the results of the simultaneous significance test ( $F$ test), the result of fcount is $2.497<$ ftabel 6.94 with a 
significance level of 0.198>0.05, so Ho is accepted and Ha is rejected. The conclusion of these calculations is Return On Assets and Earning Per Share simultaneously does not affect the Stock Price.

Keywords: Return On Assets; Earning Per Share; Stock Prices.

\section{PENDAHULUAN}

\section{A. Latar Belakang}

Dalam perusahaan yang telah go public, sangat penting bagi mereka untuk mengetahui pergerakan saham yang terjadi terlepas dari ukuran pergerakannya, karena meningkatnya nilai saham perusahaan akan menarik investor untuk menanamkan modalnya di perusahaan. Salah satu metode yang banyak digunakan oleh investor atau investor untuk berinvestasi adalah dengan membagi kepemilikan suatu perusahaan di pasar modal."

"Jika dibandingkan dengan investasi lain, berinvestasi dalam saham memungkinkan investor untuk mendapatkan pengembalian atau laba yang lebih besar dalam waktu yang relatif singkat (return tinggi) walaupun saham tersebut juga memiliki sifat risiko tinggi, yaitu ketika harga saham juga bisa turun dengan cepat. Karena itu, dalam berinvestasi, setiap investor harus mempertimbangkan hubungan trade-off antara pengembalian dan risiko. semakin tinggi pengembalian yang diharapkan oleh investor, semakin besar risiko yang harus ditanggung perusahaan.

Dalam berinvestasi dipasar modal harga saham yang selalu mengalami peningkatan merupakan salah satu indikator keberhasilan suatu perusahaan, karena harga saham yang cukup tinggi akan memberikan keuntungan berupa capital gain dan citra yang lebih baik bagi manajemen untuk mendapatkan dana dari luar perusahaan. turunnya perdagangan harga saham suatu perusahaan dipasar modal ditentukan oleh kekuatan pasar, dalam arti permintaan dan penawaran harga saham itu sendiri.

Dalam berinvestasi dipasar modal investor perlu memiliki sejumlah informasi yang berkaitan dengan dinamika harga saham agar investor dapat mengambil keputusan tentang saham perusahaan yang layak untuk dimiliki. Informasi yang dapat dijadikan acuan bagi investor untuk meminimalisir resiko investasi pada suatu perusahaan yaitu dengan melakukan analisis terhadap laba per saham yang dihasilkan perusahaan pada ahir tahun dengan melihat laporan keuangan pada perusahaan tersebut.

Laporan keuangan juga dapat digunakan untuk menghitung seberapa besar pertumbuhan pendapatan yang telah dicapai perusahaan terhadap keuntungan atas saham perusahaan tersebut. Nilai suatu perusahaan merupakan suatu prestasi yang dapat dilihat dari kinerja keuangannya, maka untuk menilai prestasi suatu perusahaan yaitu dengan mengetahui return on assets (ROA) dan earning per share (EPS) yang dihasilkan oleh perusahaan. karena dengan begitu para investor dapat memperkirakan keuntungan yang akan didapat dari dana yang di investasikannya terhadap saham yang dimiliki.

Return on Asset (ROA) mengukur kemampuan perusahaan untuk menghasilkan laba dari aset yang digunakan. Positive Return On Assets (ROA) menunjukkan bahwa dari total aset yang digunakan untuk beroperasi, perusahaan mampu memberikan keuntungan bagi perusahaan. sebaliknya jika Return On Asset (ROA) negatif menunjukkan bahwa dari total aset yang 
digunakan, perusahaan akan rugi. Jadi jika suatu perusahaan memiliki Return On Asset (ROA) yang tinggi, perusahaan tersebut memiliki peluang besar untuk meningkatkan pertumbuhan modalnya sendiri.

Earning Per Share (EPS) adalah rasio pasar yang digunakan untuk mengukur seberapa besar pengakuan pasar yang dimiliki perusahaan dengan membandingkan laba bersih dengan jumlah saham yang beredar di pasar. Informasi Earning Per Share (EPS) suatu perusahaan menunjukkan jumlah laba bersih perusahaan yang siap dibagikan kepada semua pemegang saham perusahaan. Peningkatan Earning Per Share (EPS) menunjukkan bahwa perusahaan telah berhasil meningkatkan kesejahteraan investor dengan pembagian dividen. Ini dapat meningkatkan permintaan investor untuk saham yang akan menyebabkan harga saham perusahaan meningkat.

Berdasarkan penjelasan diatas maka penulis ingin meneliti tentang pengaruh Return On Assets (ROA), Earning Per Share (EPS) dan Harga Saham pada PT. Ultrajaya Tbk yang didirikan pada tanggal 2 November 1971 dan mulai beroperasi secara komersial pada awal 1974. selanjutnya pada tanggal $15 \mathrm{Mei}$ tahun 1990 PT. Ultrajaya memperoleh ijin menteri keuangan Republik Indonesia untuk melakukan penawaran umum saham perdana (IPO). Setelah PT. Ultrajaya Tbk mencatatkan sahamnya pada Bursa Efek Indonesia (BEI), Saham PT. Ultrajaya diketahui dari tahun ke tahun selalu mengalami kenaikan dan penurunan (fluktuatif). Untuk mengetahui seberapa besar kenaikan dan penurunan Harga Saham yang dipengaruhi oleh Return On Assets (ROA) dan Earning Per Share (EPS) pada PT. Ultrajaya Tbk, penulis melakukan penelitian melalui data laporan keuangan PT.Ultrajaya Tbk, tahun 2010 sampai dengan tahun 2016.

Berdasarkan laporan keuangan PT. Ultrajaya Tbk tahun 2010 nilai Return On Assets (ROA) sebesar 5,34\% sedangkan Earning Per Share (EPS) yang dihasilkan sebesar Rp.37,- dan Harga Saham Rp.1.210,-selanjutnya pada tahun 2011, Return On Assets (ROA) PT. Ultrajaya Tbk mengalami penurunan sebesar 0,69\% menjadi 4,65\% sedangkan Earning Per Share (EPS) yang dihasilkan menurun sebesar Rp.2,- menjadi Rp.35,- dan Harga Saham juga menurun Rp.130,- menjadi Rp. 1.080,-. Kemudian pada tahun 2012, Return On Assets (ROA) PT. Ultrajaya Tbk mengalami kenaikan sebesar 9,96\% menjadi $14,61 \%$ sedangkan Earning Per Share (EPS) yang dihasilkan meningkat sebesar Rp.87,menjadi Rp.122,- dan Harga Saham juga mengalami kenaikan Rp.250,- menjadi RP. 1.330,-. Pada tahun 2013, Return On Assets (ROA) PT. Ultrajaya Tbk mengalami penurun sebesar 3,05\% menjadi 11,56\% sedangkan Earning Per Share (EPS) yang dihasilkan menurun sebesar Rp.9,- menjadi Rp.113,- dan Harga Saham mengalami kenaikan yang signifikan Rp. 3.170,- menjadi Rp. 4500,-. Pada tahun 2014, Return On Assets (ROA) PT. Ultrajaya Tbk mengalami penurunan kembali sebesar Rp. 1,85\% menjadi 9,71\% sedangkan Earning Per Share (EPS) yang dihasilkan menurun sebesar Rp. 15,- menjadi Rp.98,- dan Harga Saham juga menurun Rp.780,- menjadi Rp.3.720,-. Berdasarkan hasil penelitian terdahulu yang berkaitan dengan penelitin yang dilakukan ini adalah menurut Trisna Apriliani (2011), meneliti tentang "Pengaruh Earning Per Share (EPS) dan Return On Assets (ROA) terhadap Harga Saham PT Mustika Tbk tahun 2005 - 2010" dengan hasil penelitian yaitu secara parsial Earning Per Share memiliki pengaruh signifikan terhadap Harga Saham sedangkan Return 
On Assets (ROA) tidak berpengaruh signifikan terhadap Harga Saham. Untuk uji simultan Earning Per Share (EPS) dan Return On Assets (ROA) berpengaruh signifikan terhadap Harga Saham.

Berdasarkan uraian yang telah dikemukakan diatas maka penulis bermaksud melakukan penelitian dengan judul "PENGARUH RETURN ON ASSETS (ROA) DAN EARNING PER SHARE (EPS) TERHADAP HARGA SAHAM PADA PT. ULTRAJAYA TbK TAHUN 2010 - 2016".

\section{B. Perumusan Masalah}

Berdasarkan uraian latar belakang dan identifikasi masalah diatas, maka peneliti dapat merumuskan masalah yang akan dibahas dalampenelitian ini, yaitu sebagai berikut

1. Bagaimana pengaruh Return on Assets (ROA) terhadap harga saham pada PT. Ultrajaya Tbk dari tahun 2010 sampai dengan tahun 2016 ?

2. Bagaimana pengaruh Earning Per Share (EPS) terhadap harga saham pada PT. Ultrajaya Tbk dari tahun 2010 sampai dengan tahun 2016 ?

3. Bagaimana pengaruh Return on Assets (ROA) dan Earning Per Share (EPS) terhadap harga saham pada PT. Ultrajaya Tbk dari tahun 2010 sampai dengan 2016 ?

\section{Tujuan Penelitian}

Mengacu kepada perumusan masalah, penelitian ini bertujuan untuk menemukan bukti empiris atas hal-hal sebagai berikut:

1. Untuk mengetahui pengaruh Return On Assets (ROA) terhadap Harga Saham pada PT. Ultrajaya Tbk dari tahun 2010 sampai dengan 2016.

2. Untuk mengetahui pengaruh Earning Per Share (EPS) terhadap Harga Saham pada PT. Ultrajaya Tbk dari tahun 2010 sampai dengan 2016.

3. Untuk mengetahui pengaruh Return On Assets (ROA) dan Earning Per Share (EPS) terhadap Harga Saham pada PT. Ultrajaya Tbk dari tahun 2010 sampai dengan 2016.

\section{Kerangka Pemikiran}

Beberapa ahli memberikan definisi sebagai berikut, kerangka berfikir adalah gambaran mengenai hubungan antar variabel dalam suatu penelitian yang diuraikan oleh jalan pikiran menurut kerangka logis menurut Muhammad (2009:75). Sedangkan menurut Ridwan (2009:25) kerangka berfikir adalah dasar pemikiran dari penelitian yang disintesiskan dari fakta - fakta, observasi dan tela'ah penelitian. kerangka pikir memuat teori, dalil atau konsep - konsep yang akan dijadikan dasar dalam penelitian.

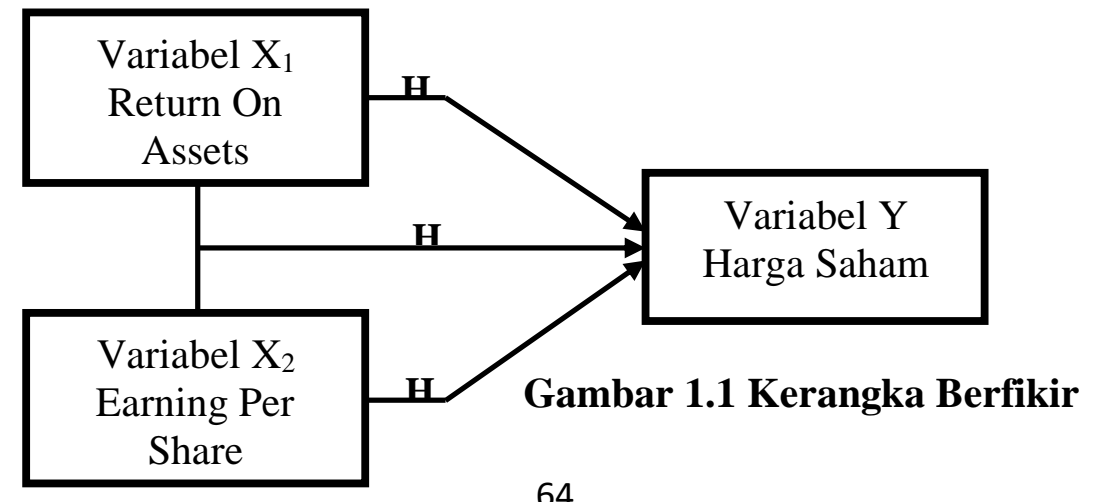




\section{E. Hipotesis}

Hipotesis menurut sugiono (2009:64) “ merupakan jawaban sementara terhadap rumusan masalah penelitian". Dari kutipan diatas, hipotesis yaitu suatu pernyataan yang bersifat sementara atau dengan anggapan, pendapat atau asumsi yang mungkin benar dan mungkin salah.

Dari uraian diatas, maka hipotesis yang dapat dirumuskan adalah :

Ho1 : $\mathrm{P}=0$, Diduga tidak adanya pengaruh Return on Assets (ROA) terhadap harga saham (Y) pada PT. ULTRAJAYA, Tbk.

Ha1 : $\mathrm{P} \neq 0$, Diduga adanya pengaruh Return on Assets (ROA) terhadap Harga Saham (Y) pada PT. ULTRAJAYA, Tbk.

Ho2 : $\mathrm{P}=0$, Diduga tidak adanya pengaruh Earning Per Share (EPS) terhadap Harga Saham (Y) pada PT. ULTRAJAYA, Tbk.

Ha2 : $\mathrm{P} \neq 0$, Diduga adanya pengaruh Earning Per Share (EPS) terhadap Harga Saham (Y) pada PT. ULTRAJAYA, Tbk.

Ho3 : $\mathrm{P}=0$, Diduga tidak adanya pengaruh Return on Assets (ROA) dan Earning Per Share (EPS) secara bersama - sama terhadap Harga Saham (Y) pada PT. ULTRAJAYA, Tbk.

Ha3 : $\mathrm{P} \neq 0$, Diduga adanya pengaruh Return on Assets (ROA) dan Earning Per Share (EPS) secara bersama - sama terhadap Harga Saham pada PT. ULTRAJAYA, Tbk.

\section{TINJAUAN PUSTAKA}

\section{A. Return on Asset}

ROA atau Return on Asset Riayanto (2010 : 335), "rasio ini merupakan perbandingan antara laba bersih dengan total aset. Rasio ini menunjukan seberapa besar laba bersih yang diperoleh perusahaan bila diukur dari asssetnya". Menurut Harahap (2010 : 305), "semakin besar rasionya semakin bagus karena perusahaan dianggap mampu dalam menggunakan asset yang dimilikinya secara efektif untuk menghasilkan laba”.

Return on Asset sering kali dipakai oleh manajemen puncak untuk mengevaluasi unit - unit bisnis didalam suatu perusahaan multidivisional. ROA dapat dihitung dengan rumus sebagai berikut :

$$
R O A=\frac{\text { net profit after tax }}{\text { total assets }} \times 100 \%
$$

\section{B. Earning Per Share}

Menurut kasmir (2015 : 207) “Earning Per Share (EPS) adalah rasio untuk mengukur keberhasilan manajemen dalam mencapai keuntungan bagi pemegang saham. rasio yang rendah berarti manajemen belum berhasil memuaskan pemegang saham, sebaliknya dengan rasio yang tinggi, maka kesejahteraan pemegang saham meningkat. Dengan kata lain tingkat pengembalian yang tinggi".

Rumus untuk menghitung EPS suatu perusahaan adalah sebagai berikut :

$$
E P S=\frac{\text { Laba Bersih Setalah Pajak }(E A T)}{\text { Jumlah Saham Biasa Yang Beredar }}
$$




\section{Harga Saham}

Menurut jogiyanto (2009: 88), "harga saham merupakan harga saham yang terjadi dipasar bursa pada saat tertentu yang ditentukan oleh pelaku pasar. Nilai pasar ini ditentukan oleh permitaan dan penawaran saham yang bersangkutan di pasar bursa".

Menurut tryfino (2009: 69), "pengaruh pergerakan indeks dikawasan regional dapat mempengaruhi pergerakan indeks di BEI, terutama jika kondisi dalam negeri sepi sentiment". Hal ini menggambarkan bahwa indeks diseluruh dunia sudah terintegrasi.

Kanaikan indeks harga saham gabungan sepanjang waktu tertentu, tentunya menandakan kondisi investasi dan perekonomian negara dalam keadaan baik. Sebaliknya jika turun berarti iklim investasi sedang buruk. Kondisi demikian akan mempengaruhi naik turunnya harga saham dipasar bursa.

\section{METODOLOGI PENELITIAN}

\section{A. Tempat dan Waktu Penelitian}

Objek penelitian yang dipilih penulis adalah PT. Ultrajaya, Tbk. Untuk memperoleh data dan informasi dalam penulisan skripsi ini, penelitian dilakukan pada perusahaan yang terdaftar di Bursa Efek Indonesia (BEI) yang berlokasi di Indonesian Stock Exchange Building tower 2, lantai 1 jalan jendral sudirman kav. 52 - 53 Jakarta 12190. Waktu penelitian dilakukan selama 3 (tiga) bulan, mulai bulan Mei sampai dengan bulan Agustus.

\section{B. Metode Penelitian}

Penelitian ini bersifat deskriptif kuantitatif, yaitu melakukan pembahasan atas permasalahan yang dihadapi perusahaan terhadap penilaian pasar dari segi keuangan. Menurut Sugiono (2013 : 28) "deskriptif kuantitatif yaitu data yang berbentuk angka atau data kualitatif yang diangkakan / scoring".

\section{Populasi dan Sampel}

\section{Populasi}

Munurut sugiyono (2013:80) "Populasi adalah wilayah generalisasi yang terdiri atas objeck atau subjekyang mempunyai kualitas dan karakteristik tertenru yang ditetapkan peneliti untuk di pelajari kemudian ditarik kesimpulanya". Maka Populasi yang digunakan dalam penelitian ini adalah seluruh laporan keuangan pada PT. Ultrajaya, Tbk.

\section{Sampel}

Menurut Sugiono (2013:149) "sampel adalah bagian dari jumlah dan karakteristik yang dimiliki oleh populasi tersebut". Sampel yang digunakan yaitu berupa laporan keuangan meliputi neraca dan laporan laba rugi pada PT. Ultrajaya, Tbk periode 2010 - 2016.

\section{Jenis dan Sumber Data}

Sumber data yang diperlukan dalam penelitian ini terdiri dari:

1. Data Primer 
Menurut Mudrajad Kuncoro (2009:148) "data primer adalah data yang diolah dengan survei lapangan yang menggunakan semua metode pengumpulan data original". Cara pengumpulan data ini diperoleh dari wawancara dan observasi langsung di tempat penelitian.

2. Data Sekunder

Menurut Mudrajad Kuncoro (2009:148) “data sekunder adalah data yang telah dikumpulkan oleh lembaga pengumpul data dan dipublikasi kepada masyarakat pengguna data”. Data yang digunakan dalam penelitian ini diperoleh dari laporan keuangan PT.Ultrajaya Tbk berupa laporan neraca dan laporan laba rugi.

\section{E. Metode Analisis Data}

Metode yang digunakan dalam penelitian ini adalah:

\section{Analisis Deskriptif}

Menurut sugiono (2011:199) "analisis statistik deskriptif adalah statistik yang digunakan untuk menganalisis data dengan cara mendeskripsikan atau menggambarkan data yang telah terkumpul sebagaimana adanya tanpa bermaksud membuat kesimpulan yang berlaku untuk umum atau generalisasi".

\section{Uji Asumsi Klasik}

\section{a. Uji Normalitas}

Uji ini bertujuan untuk mengguji apakah dalam model regresi, variabel memiliki disrtibusi normal.

"Dasar pengambilan uji Normalitas adalah jika signifikan lebih besar dari a=5\% maka menunjukan distribusi data normal", Ghozali (2005:105):

1) Jika data menyebar di sekitar garis diagonal dan mengikuti arah garis diagonal atau grafik histogram menunjukkan distribusi normal, maka model regresi memenuhi asumsi normalitas.

2) Jika data menyebar jauh dari diagonal atau tidak mengikuti arah garis diagonal atau grafik histogram tidak menunjukkan distribusi normal, maka model regresi tidak memenuhi asumsi normalitas.

b. Uji Multikolinieritas

"Uji multikolineritas dilakukan dengan melihat tolerance value dan Variance Inflation Factor (VIF). Metode ini ditujukan untuk mendeteksi variabel-variabel mana yang menyebabkan terjadinya multikolinearitas", menurut Ghozali (2005:92). Pedoman suatu model regresi yang bebas multikolinieritas adalah yang mempunyi nilai VIF disekitar angka 1 dan angka tolerance mendekati 1. Batas VIF adalah 10, jika nilai VIF dibawah 10, maka tidak terjadi gejala multikolinieritas atau sebaliknya

\section{c. Uji Autokorelasi}

Uji heterokedastisitas untuk menguji apakah pada model regresi terjadi ketidak samaan varian dari residual dari satu pengamatan kepengamatan lain, salah satu cara untuk melihat adanya problem heterokedastisitas adalah dengan melihat grafik plot antara nilai prediksi variabel terikat (Zpred) dengan residualnya (Sresid) (Tony Wijaya, 2012:124). 


\section{Analisis Regresi Linear Berganda}

Persamaan umum regresi berganda menurut Sugiyono (2010:277) adalah:

$\mathbf{y}=\boldsymbol{\alpha}+\boldsymbol{\beta}_{1} \mathbf{x}_{1}+\boldsymbol{\beta}_{2} \mathbf{x}_{2}+\varepsilon$

dimana:

$\mathrm{y}=$ Harga Saham

$\mathrm{x}_{1}=R O A$

$\mathrm{x}_{2}=E P S$

$\alpha=$ konstan, adalah nilai terkait yang dalam hal ini adalah $\mathrm{y}$ at ketika variabel independen adalah $0(\mathrm{x} 1, \mathrm{x} 2,=0)$

$\beta 1=$ koefisien regresi berganda antara variabel bebas $x 1$ terhadap variabel terikat ke $\mathrm{y}$, jika variabel independen $\mathrm{x} 2$, dianggap konstan

$\beta 2=$ koefisien regresi berganda antara variabel bebas $\mathrm{x} 2$ dengan variabel terikat ke $\mathrm{y}$, jika variabel independen $\mathrm{x} 1$, dianggap konstan

$\varepsilon=$ faktor lain yang mempengaruhi variabel yModel diatas menunjukan bahwa variabel dependen $\mathrm{Y}$ dipengaruhi oleh dua variabel independen $\mathrm{x}_{1}, \mathrm{x}_{2}$ (ROA dan EPS).

\section{Desain Pengujian Hipotesis}

a. Uji T

Uji t digunakan untuk mengetahui besarnya pengaruh masing-masing variabel independen dalam hal ini adalah ROA dan EPS, terhadap harga saham.

b. Tes F

Uji $F$ digunakan untuk mengetahui besarnya pengaruh variabel independen dalam hal ini adalah ROA dan EPS terhadap harga saham secara simultan. Tes ini dilakukan dengan membandingkan nilai Fcalculate dengan nilai Ftable. Nilai Fcount dapat ditentukan dengan bantuan perangkat lunak SPSS.

c. Uji Koefisien Determinasi

Koefisien uji determinasi adalah tes data yang dilakukan untuk mengetahui pengaruh semua variabel independen secara bersama-sama terhadap variabel dependen.

\section{HASIL DAN PEMBAHASAN}

\section{A. Analisis Statistik Deskriptif}

Statistik deskriptif menunjukkan jumlah data $(\mathrm{N})$ yang digunakan dalam penelitian ini dan dapat menunjukkan nilai maksimum, nilai minimum, nilai rata-rata dan standar deviasi dari masing-masing variabel yang diteliti, antara lain Retrun On Assets (ROA), Earning Per Sharen (EPS), dan Harga Saham. Adapun hasil olahan statistik deskriptif data yang menjadi variabel penelitian dengan menggunakan SPSS versi 20 disajikan pada tabel 4.4 dibawah ini: 


\section{Tabel 4.4}

Hasil Analisis Deskriptif

\begin{tabular}{|l|r|r|r|}
\hline \multicolumn{1}{|c|}{ Descriptive Statistics } \\
\hline Hean & \multicolumn{1}{|c|}{ Std. Deviation } & \multicolumn{1}{|c|}{ N } \\
Harga Saham & 2907,8571 & 1619,99449 & 7 \\
ROA & 11,0557 & 4,73607 & 7 \\
EPS & 118,7143 & 75,40494 & 7 \\
\hline
\end{tabular}

(Sumber: Hasil Olahan Data SPSS versi 20)

Berdasarkan hasil perhitungan tabel diatas dapat diketahui jumlah data (N) yang digunakan sebanyak 7 data. Nilai variabel Harga Saham rata - rata (mean) sebesar 2907,8571 dengan nilai standar devisiasinya sebesar 1619,99449 sedangkan variabel ROA mempunyai nilai rata - rata sebesar 11,0557 dengan nilai standar devisiasinya 4,73607 sedangkan variabel EPS mempunyai nilai rata - rata sebesar 118,7143 dengan nilai standar devisiasinya sebesar 75,40494.

\section{B. Pengujian Asumsi Klasik}

\section{Uji Normalitas}

Uji normalitas bertujuan untuk menguji apakah dalam model regresi variabel dependen dan variabel independen keduanya memiliki distribusi normal atau tidak. Hasil data uji normalitas pada variabel ROA dan EPS pada HARGA SAHAM diperoleh hasil sebagai berikut :

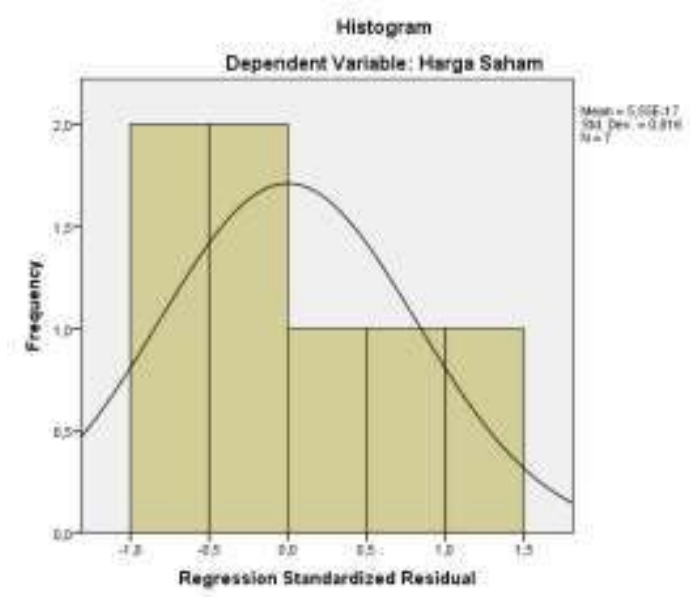

Grafik 4.5

\section{Histogram Uji Normalitas}

(Sumber: Hasil Olahan Data SPSS versi 20)

Berdasarkan data histogram di atas dapat dilihat bahwa kurva tersebut memiliki nilai histogram yang berdistribusi normal. Hal ini dapat dilihat dari nilai - nilai residual yang terdistribusi normal. Karena uji normalitas bukan dilakukan pada masing-masing variabel tetapi pada nilai residualnya. Analisis lebih lanjut dengan menggunakan Normal Probability Plot of Regression Standardized Residual dapat dilihat pada gambar dibawah ini : 


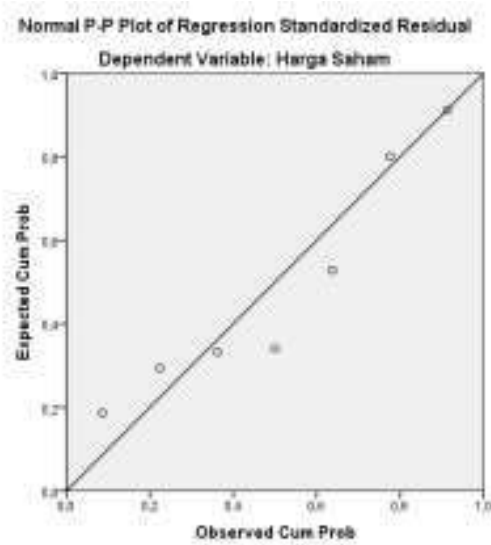

Grafik 4.6

Normal Probability Plot

(Sumber: Hasil Olahan Data SPSS versi 20)

Dari gambar di atas dapat disimpulkan bahwa nilai residu terdistribusi normal karena distribusi data residu terlihat mendekati garis normal. Pengujian normalitas data dengan analisis statistik dapat dilakukan dengan menggunakan Uji Kolmogorov-Smirnov. Secara multivarians pengujian normalitas data dilakukan terhadap nilai residualnya.

Secara umum uji normalitas digunakan untuk melihat varians nilai dan kemungkinan bahwa nilai tersebut dapat mendekati pada nilai populasi secara keseluruhan. Uji normalitas ini dapat mengetahui kemungkinan sampel yang diambil apakah dapat menggambarkan atau mewakili keseluruhan populasi. Namun perlu di ingat bahwa uji normalitas bukan hal yang menentukan berkelanjutan penelitian tetapi hanya ingin melihat seberapa besar kemampuan sampel yang diambil dapat mewakili populasi karena besar atau kecilnya sampel yang diambil sangatlah mempengaruhi terhadap nilai normalitas.

\section{Uji Multikolineritas}

Uji multikolinieritas bertujuan untuk menguji apakah model regresi menemukan korelasi antara variabel independen. Dalam model regresi yang baik seharusnya tidak ada korelasi antara variabel independen. Untuk mendeteksi ada atau tidaknya multikolinieritas dalam model ini adalah dengan melihat nilai tolerance dan variance inflation factor (VIF).

Jika nilai tolerance $>0,10$ dan VIF $<10,00$ maka dapat diartikan bahwa tidak terdapat multikolineritas pada penelitian tersebut, begitu juga sebaliknya jika nilai tolerance $<0,10$ dan VIF $>10,00$ maka terdapat multikolinearitas. 
Tabel 4.5

\section{Hasil Uji Multikolinearitas}

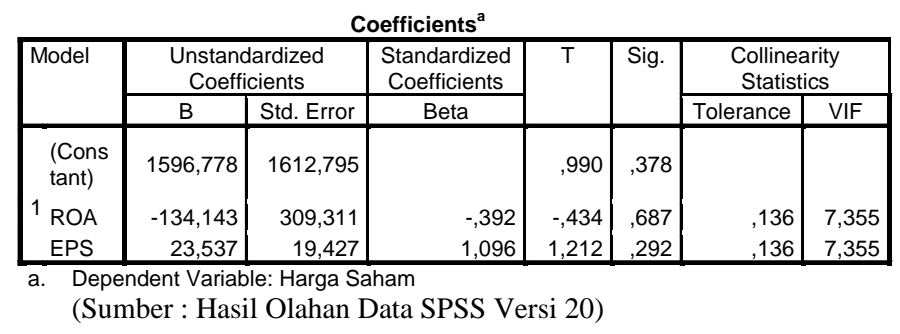

Suatu model regresi dinyatakan bebas dari multikolinearitas adalah jika mempunyai Tolerance lebih besar dari 0,10 dan nilai VIF lebih kecil dari 10 Berdasarkan tabel diatas, maka dapat diketahui nilai VIF untuk masing masing variabel penelitian sebagai berikut:

a. Nilai VIF untuk variabel ROA sebesar $7,355<10$, sehingga variabel ROA dinyatakan tidak terjadi multikolinearitas.

b. Nilai VIF untuk variabel EPS sebesar 7,335 < 10, sehingga variabel EPS dinyatakan tidak terjadi multikolinearitas.

Data yang digunakan untuk uji multikolinearitas ini adalah data variabel independen. Dari tabel tersebut diperoleh bahwa semua variabel bebas memiliki nilai Tolerance lebih dari 1 dan nilai VIF kurang dari 10 dengan demikian dalam model ini terbebas dari multikolinearitas dan layak untuk digunakan.

\section{Uji Heteroskedastisitas}

Uji heteroskedastisitas bertujuan untuk menguji apakah dalam model regresi terdapat ketidaksamaan varian dari satu residual ke residual lainnya. Jika varians dari sisa satu pengamatan ke pengamatan lain tetap, maka itu disebut homoseksualitas-dasticity dan jika berbeda itu disebut heteroskedastisitas. Cara untuk mendeteksi ada atau tidaknya heteroskedastisitas adalah dengan melihat grafik sebar plot antara nilai prediksi variabel dependen, yaitu ZPRED dan SRESID residual. Hasil analisis adalah sebagai berikut:

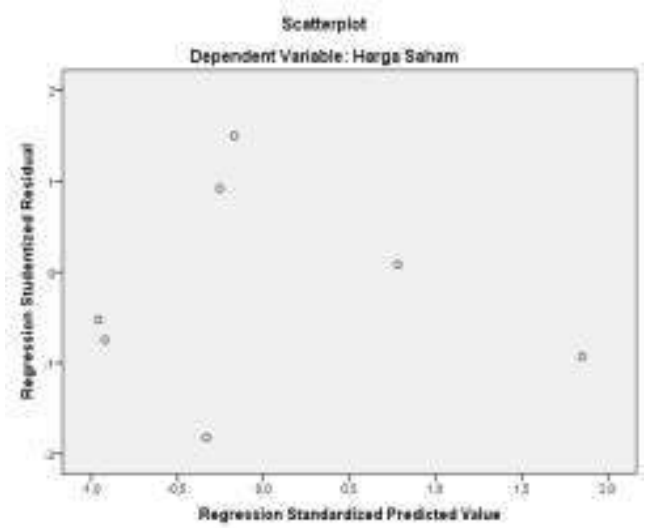

Gambar 4.7 Uji Heteroskedastisitas

(Sumber: Hasil Olahan Data SPSS versi 20) 
Berdasarkan pada gambar 4.7 diatas dapat diketahui bahwa data titik - titik menyebar secara merata diatas dan dibawah garis nol, tidak terkumpul disatu tempat, serta tidak membentuk pola tertentu sehingga dapat disimpulkan bahwa pada uji regresi ini tidak terjadi masalah heteroskedastisitas.

\section{Uji Autokorelasi}

Uji autokorelasi bertujuan untuk menguji apakah dalam model linier ada korelasi kesalahan pengganggu pada periode $t$ dengan kesalahan pada periode t-1 (sebelumnya). Model regresi yang baik adalah regresi yang bebas dari autokorelasi. Cara yang dapat digunakan untuk mendeteksi ada atau tidaknya autokorelasi adalah dengan uji Durbin-Watson (D-W). Dari hasil pengolahan data, maka diperoleh hasil sebagai berikut.

Tabel 4.6

\section{Durbin - Watson}

\begin{tabular}{|l|r|r|r|r|r|}
\hline Model & $\mathrm{R}$ & R Square & $\begin{array}{c}\text { Adjusted R } \\
\text { Square }\end{array}$ & $\begin{array}{c}\text { Std. Error of the } \\
\text { Estimate }\end{array}$ & $\begin{array}{c}\text { Durbin- } \\
\text { Watson }\end{array}$ \\
\hline 1 &, $745^{\mathrm{a}}$ &, 555 &, 333 & 1323,12332 & 1,575 \\
\hline
\end{tabular}
a. Predictors: (Constant), EPS, ROA
b. Dependent Variable: Harga Saham

(Sumber : Hasil Olahan Data SPSS Versi20)

Berdasarkan hasil output pada tabel 4.6 didapat nilai DW sebesar 1,575 nilai ini akan dibandingkan menggunakan nilai signifikan sebesar 5\% atau 0,05 . Untuk jumlah data $\mathrm{n}=7$ maka nilai $\mathrm{dL}=0,4672$ dan $\mathrm{dU}=1,8964$. Karena nilai DW yang diperoleh sebesar 1,575 lebih kecil dari dU dan kurang dari 4-dU $(4-1,8964=2,1036)$ maka dapat disimpulkan bahwa tidak terdapat autokorelasi pada penelitian ini.

\section{Analisi Linier Regresi Berganda}

Analisis linier berganda adalah hubungan linier antara dua atau lebih variabel independen (X1, X2 ... Xn) dengan variabel dependen (Y). Model persamaan regresi linier berganda digunakan untuk menjelaskan hubungan antara satu variabel dependen dengan lebih dari satu variabel independen. Dalam penelitian ini model persamaan regresi linier berganda di susun untuk mengetahui pengaruh antara Return On Assets (ROA) dan Earning Per Share (EPS) sebagai variable independen terhadap Harga Saham sebagai variable dependen. Hasil persamaan regresi adalah sebagai berikut : 
Tabel 4.7

Regresi Linear Berganda

\begin{tabular}{|c|c|c|c|c|c|}
\hline \multicolumn{6}{|c|}{ Coefficients $^{\mathrm{a}}$} \\
\hline \multirow[t]{2}{*}{ Model } & \multicolumn{2}{|c|}{ Unstandardized Coefficients } & \multirow{2}{*}{$\begin{array}{c}\begin{array}{c}\text { Standardized } \\
\text { Coefficients }\end{array} \\
\text { Beta }\end{array}$} & \multirow[t]{2}{*}{$t$} & \multirow[t]{2}{*}{ Sig. } \\
\hline & $B$ & Std. Error & & & \\
\hline (Constant) & 1596,778 & 1612,795 & & ,990 & ,378 \\
\hline $1 \mathrm{ROA}$ & $-134,143$ & 309,311 &,- 392 &,- 434 & 687 \\
\hline EPS & 23,537 & 19,427 & 1,096 & 1,212 & ,292 \\
\hline
\end{tabular}

(Sumber : Hasil Olahan Data SPSS Versi 20)

Berdasarkan tabel 4.7 maka persamaan regresi linier berganda

dengan 2 variabel independen sebagai berikut:

$\mathrm{Y}=1.596,778-134,143 \mathrm{X}_{1}+23,537 \mathrm{X}_{2}$

Persamaan regresi tersebut dapat dijelaskan sebagai berikut:

a. Koefisien Konstanta (a) sebesar 1.596,778

Dari persamaan diatas diketahui konstanta sebesar 1.596,778 hal ini menunjukan jika variabel independen yaitu Return On Assets dan Earning Per Share bernilai 0 (nol) maka Harga Saham sebesar $1.596,778$.

b. Variabel Return On Assets ( $\left.\mathrm{X}_{1}\right)$ sebesar -134,143

Dari persamaan diatas diketahui variabel Return On Assets benilai negatif hal ini menyatakan bahwa setiap kali terjadi perubahan 1 kali pada Return On assets, maka akan terjadi penurunan Harga Saham sebesar 134,143. Dengan asumsi variabel lain tetap (variabel lain sama dengan nol)

c. Variabel Earning Per Share $\left(\mathrm{X}_{2}\right)$ sebesar 23,537

Dari persamaan diatas diketahui variabel Earning Per Share benilai positif hal ini menunjukan bahwa setiap kali terjadi perubahan sebesar 1 kali pada Earning Per Share, maka akan terjadi peningkatan nilai Harga Saham sebesar 23,537 secara positif berjalan searah dengan Harga Saham. Dengan asumsi variabel lain tetap (variabel lain sama dengan nol).

\section{Uji Signifikan Parsial (Uji t)}

Uji t digunakan untuk menunjukkan sejauh mana pengaruh masingmasing variabel independen secara individual dalam menjelaskan variasi variabel dependen. Pada Uji t, nilai t yang dihitung akan dibandingkan dengan nilai $t$ tabel. Berikut ini adalah hasil perhitungan uji t.

\section{Tabel 4.8}

Hasil Uji signifikansi parsial (uji t)

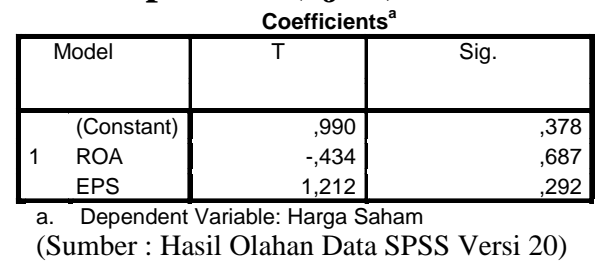


Rumus $\mathrm{t}_{\text {tabel }}$ yaitu $\mathrm{df}=\mathrm{n}$ (banyaknya data) $-\mathrm{k}$ (jumlah variabel independen ditambah variabel dependen $)=7-3=4$ dan taraf signifikansi $=$ 0,05 maka diperoleh $t_{\text {tabel }}=2,776$

Berdasarkan output Cofficients di atas, diketahui bahwa nilai koefisien regresi variabel independen yaitu Return On Assets (ROA) dan Earning Per Share (EPS) sebagai berikut:

1. Pengaruh Return On Assets (ROA) terhadap Harga Saham

Nilai $t_{\text {hitung }}$ dari variabel Return On Assets adalah - 434 lebih kecil dari nilai $t_{\text {tabel }}$ sebesar 2,776 dengan tingkat signifikan 0,687 lebih besar dari 0,05. Dengan demikian Ho diterima, artinya secara parsial tidak terdapat pengaruh yang signifikan dari perubahan Return On Assets (ROA) terhadap harga saham.

2. Pengaruh Earning Per Share (EPS) terhadap Harga Saham

Nilai thitung dari variabel Earning Per Share (EPS) adalah 1,212 lebih kecil dari nilai $t_{\text {tabel }}$ sebesar 2,776 dengan tingkat signifikan 0,292 lebih besar dari 0,05. Dengan demikian Ho diterima artinya secara parsial tidak terdapat pengaruh yang signifikan dari perubahan Earning Per Share (EPS) terhadap Harga Saham.

\section{Uji Signifikan Simultan F (Uji F)}

Uji F disebut juga uji global atau uji signifikansi serentak atau simultan. Uji ini digunakan untuk mengetahui apakah Return On Assets (ROA) dan Earning Per Share (EPS) secara bersama - sama berpengaruh signifikan terhadap Harga Saham. Hasil perhitungan uji F sebagai berikut:

Table 4.9

\begin{tabular}{|c|c|c|c|c|c|}
\hline \multicolumn{6}{|c|}{ Hasil Uji Sigifikansi Simultan F (uji F) } \\
\hline Model & Sum of Squares & Df & Mean Square & & \\
\hline $\begin{array}{l}\text { Regression } \\
\end{array}$ & 8743671,549 & 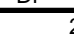 & 4371835,774 & 2,497 & $\frac{198^{\circ}}{, 19}$ \\
\hline 1 Residual & 7002621,308 & 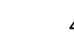 & 1750655,327 & & \\
\hline Total & 15746292,857 & & & & \\
\hline
\end{tabular}

Pada tabel diatas dapat dilihat bahwa hasil Uji F menunjukkan nilai $F_{\text {hitung }}$ sebesar 2,497 sedangkan $\mathrm{F}_{\text {tabel }}$ sebesar 6,94 berarti 2,497 $<6,94$ dengan nilai signifikasi sebesar 0,198 > 0,05. Dengan demikian Ho diterima dan Ha ditolak, artinya secara simultan dapat dibuktikan Return On Assets (ROA) dan Earning Per Share (EPS) secara bersama - sama tidak berpengaruh signifikan terhadap Harga Saham.

\section{Uji Koefisien Determinasi $\left(\mathbf{R}^{2}\right)$}

Koefisien determinasi (R2) digunakan untuk menentukan kekuatan pengaruh variabel independen terhadap variabel dependen. Hal itu dapat dilihat dari besarnya koefisien determinasi (R2), yang berbeda antara nol dan satu. Nilai yang mendekati satu berarti bahwa variabel independen menyediakan hampir semua informasi yang diperlukan untuk memprediksi variasi variabel dependen. Dari hasil pengolahan data, hasil berikut diperoleh. 
Tabel 4.10

\section{Uji Koefisien Kolerasi}

\begin{tabular}{|l|r|r|r|c|}
\hline Model & $\mathrm{R}$ & $\mathrm{R}$ Square & $\begin{array}{c}\text { Adjusted R } \\
\text { Square }\end{array}$ & $\begin{array}{c}\text { Std. Error of the } \\
\text { Estimate }\end{array}$ \\
\hline 1 &, $745^{\text {a }}$ &, 555 &, 333 & 1323,12332 \\
\hline
\end{tabular}
a. Predictors: (Constant), EPS, ROA
b.Dependent Variable: Harga Saham
(Sumber : Hasil Olahan Data SPSS Versi 20)

Pada tabel diatas menunjukkan koefisien determinasi (R Square). Nilai R Square menjelaskan seberapa besar hubungan antar variabel - variabel independen (X) dengan variabel dependen (Y), dari hasil perhitungan diperoleh nilai $\mathrm{R}^{2}$ sebesar 0,555 atau $55,5 \%$ artinya $55,5, \%$ Pertumbuhan Harga Saham dipengaruhi oleh kedua variabel ROA dan EPS. Dan sisanya sekitar 44,5\% dipengaruhi oleh faktor - faktor lain diluar model.

Uji koefisien determinasi dapat dilihat dari nilai R Square. Dari hasil pengolahan data dapat dilihat bahwa nilai $\mathrm{R}$ Square menunjukkan angka sebesar 0,555 yang berarti bahwa variabel $\mathrm{X}_{1}$ Return On Assets (ROA) dan $\mathrm{X}_{2}$ Earning Per Share (EPS) berpengaruh cukup kuat terhadap harga saham sebesar 55,5\% sedangkan sisanya sebesar $44,5 \%$ dipengaruhi oleh faktor lain yang tidak diteliti dalam penelitian ini.

\section{KESIMPULAN}

Berdasarkan penelitian dan pembahasan pada bab - bab sebelumnya, mengenai pengaruh Return On Assets (ROA) dan Earning Per Share (EPS) terhadap Harga Saham pada PT. Ultrajaya Tbk. Periode 2010 - 2016 yang menjadi objek penelitian, maka dapat ditarik beberapa kesimpulan sebagai berikut :

1. Return On Assets (ROA) secara parsial tidak berpengaruh signifikan terhadap Harga Saham. Dengan nilai thitung dari variabel Return On Assets adalah 0,434 lebih kecil dari nilai $t_{\text {tabel }}$ sebesar 2,776 dengan tingkat signifikan 0,687 lebih besar dari 0,05. Hal ini menjelaskan bahwa Harga Saham pada PT. Ultrajaya Indonesia Tbk tidak begitu dipengaruhi oleh Return On Assets (ROA).

2. Earning Per Share (EPS) Secara parsial tidak berpengaruh signifikan terhadap Harga Saham. Dengan nilai $t_{\text {hitung }}$ dari variabel Earning Per Share (EPS) adalah 1,212 lebih kecil dari nilai $t_{\text {tabel }}$ sebesar 2,776 dengan tingkat signifikan 0,292 lebih besar dari 0,05. Hal ini menjelaskan bahwa Earning Per Share (EPS) tidak mempengaruhi Harga Saham pada PT. Ultrajaya Tbk.

3. Berdasarkan pengujian secara simultan Return On Assets (ROA) dan Earning Per Share (EPS) menunjukan bahwa nilai Fhitung lebih kecil dari pada $F_{\text {tabel }}$ yaitu $F_{\text {hitung }}$ sebesar 2,497 sedangkan $F_{\text {tabel }}$ sebesar 6,94 dan nilai signifikansi 0,198 dimana nilai ini lebih besar dari tingkat signifikansi 0,05. Maka demikian dapat disimpulkan bahwa secara simultan tidak terdapat pengaruh yang signifikan antara Return On Assets (ROA) dan Earning Per Share (EPS) terhadap Harga Saham PT. Ultrajaya Tbk. 


\section{DAFTAR PUSTAKA}

Darmaji, Tjipto dan Hendry M Fakhrudin. 2010. Pasar Modal di Indonesia. Jakarta: Salemba Empat.

Darmaji, T.H.M Fakhrudin. 2012. Pasar Modal di Indonesia Pendekatan Tanya Jawab. Jakarta: Salemba Empat.

Duwi Priatno. 2013. Mandiri Belajar Analisis Data dengan SPSS. Jakarta: Mediakom.

Fahmi, Irham. 2013. Pengantar Manajemen Keuangan. Bandung : Alfabeta.

Ghozali, Imam. 2011. Aplikasi Analisis Multivariate dengan Program

IMB SPSS 19. Edisi kelima. Semarang: Universitas Diponegoro.

Hanafi, Mahfud M. 2010. Manajemen keuangan. Cetakan ke lima. Yogyakarta: BPFE

Hasibuan, Malayu S.P. 2010. Manajemen Sumber Daya Manusia. Jakarta: PT Bumi Aksara.

Hermuningsih, Sri. 2012. Pengantar Pasar Modal Indonesia. Yogyakarta: UPP STIM YKPN.

Herry. 2016. Analisis Laporan Keuangan. Cetakan pertama. Jakarta: Grasindo.

Horne James C. Van Dan John M. Wachowiccz. 2012. Prinsip-prinsip Manajemen Keuangan. Alih bahasa Dewi Fitrisari dan Deny A.Kwary. Jakarta: Salemba Empat.

Irham Fahmi. 2014. Manajemen Keuangan Dan Pasar Modal. Edisi Pertama. Jakarta: Mitra wacana Media.

Kasmir. 2012. Analisis Laporan Keuangan. Jakarta: PT. Raja Grafindo Persada.

Kasmir. 2015. Analisis Laporan Keuangan. Edisi Kesatu, Cetakan Keempat. Jakarta: PT. Raja Grafindo Persada.

Mulyadi. 2010. Akuntansi Manajemen. Yogyakarta: UPP STIE YKPN.

Jurnal KREATIF : Pemasaran, Sumberdaya Manusia dan Keuangan, Vol. 6, No.1, Januari 2018

Rianto, Bambang, 2010. Dasar - Dasar Pembelanjaan Perusahaan. Edisi Keempat, Cetakan Ke sepuluh. Yogyakarta: BPFE.

Santoso, Singgih. 2011. Analisis SPSS pada Statistik Parametik. Jakarta: PT Elex Media Komputindo.

Siregar, Sofyan . 2012. Metode Penelitian Kuantitatif. Prenadamedia Group.

Sugiono. 2011. Metode Penelitian Kuantitatif Kualitatifdan R\&D. Bandung: Alfabeta.

Tandelin, Eduardus. 2010. Portofolio Dan Investasi Teori Dan Aplikasi. Edisi Pertama. Yogyakarta: Kanisius.

Van Home James C. 2013. Prinsip-prinsip Manajemen Keuangan. Alih Bahasa Heru Sutoyo. Jakarta: Salemba Empat.

www.ultrajaya.co.id \&amp; www.idx.co.id 